\title{
Performance, carcass traits, and non-carcass components of feedlot finished lambs from different residual feed intake classes
}

\section{Desempenho, características de carcaça e componentes não-carcaça de cordeiros confinados de diferentes classes de consumo alimentar residual}

\author{
Raizza Fátima Abadia Tulux Rocha ${ }^{1}$; Andréa Roberto Duarte Lopes Souza ${ }^{2 *}$; \\ Maria da Graça Morais ${ }^{3}$; Mayara Mitiko Yoshihara Carneiro ${ }^{1 *}$; \\ Henrique Jorge Fernandes ${ }^{4}$; Gelson Luís Dias Feijós; \\ Bruna Biava de Menezes ${ }^{1}$; Catherine Cecília Walker ${ }^{1}$
}

\begin{abstract}
This study aimed to assess the performance, carcass traits, and non-carcass components of feedlot finished Texel crossbred lambs from different residual feed intake classes (RFI). Forty-seven uncastrated male Texel crossbred lambs (3/4 Texel $+1 / 4$ Pantaneira) tested here were 4-month-old with an initial weight of $29.9 \pm 5.5 \mathrm{~kg}$. The lambs were confined for 70 days for individual dry matter intake (DMI) and average daily gain (ADG) assessment. The diet containing corn silage was provided as roughage, while the concentrate consisted of corn grain, soybean meal, urea, and mineral mixture with a 40:60 roughage to concentrate ratio and $76.34 \%$ total digestible nutrients (TDN). After confinement for 70 days, the lambs were slaughtered to assess carcass traits and non-carcass components. Based on the RFI, lambs were divided into three classes according to the standard deviation (sd): Positive RFI (inefficient, 0.5 above the mean), Negative RFI (efficient, 0.5 below the mean), and Medium RFI (intermediate). Classes with Negative (efficient) and Positive RFI (inefficient) showed no differences in ADG ( $0.321 \mathrm{vs}$ $0.306 \mathrm{~kg} ; \mathrm{P}>0.05)$. Dry matter intake $\left(\mathrm{g} \mathrm{d}^{-1}\right)$, and percentage of body weight $(\mathrm{BW})$ differed significantly between the RFI classes $(\mathrm{P}<0.05)$. Compared to lambs in the inefficient class, those in the efficient class (Negative RFI) showed a 9\% reduction in DMI and had the same ADG. The lambs in either Positive or Negative RFI classes showed no weight differences between non-carcass components $(\mathrm{P}>$ $0.05)$. The RFI classes showed no differences in shrunk body weight, hot carcass weight, hot dressing, and weight of commercial cuts $(\mathrm{P}>0.05)$. They showed no differences in neck, shoulder + shank, loin, rack, flank steak, rack cap off, and leg weights $(\mathrm{P}>0.05)$. Our results indicate that improvement in feed efficiency, as a function of the RFI index, does not compromise performance and carcass traits of Texel crossbred lambs.
\end{abstract}

Key words: Commercial cuts. Fat deposits. Feed efficiency. Feedlot. Sheep.

\footnotetext{
${ }^{1}$ Discentes, Curso de Doutorado, Programa de Pós-Graduação em Ciência Animal, Faculdade de Medicina Veterinária e Zootecnia, Universidade Federal de Mato Grosso do Sul, UFMS, Campo Grande, MS, Brasil. E-mail: raizza_ra@hotmail.com; mayara_mitiko@hotmail.com; bruna_biava@hotmail.com; catherinecwalker@hotmail.com

2 Pesquisadora, Programa de Desenvolvimento Científico Regional, DCR/CNPq/FUNDECT, Departamento de Zootecnia, Faculdade de Medicina Veterinária e Zootecnia, UFMS, Campo Grande, MS, Brasil. E-mail: andreardl_dagher@yahoo.com.br

3 Prof ${ }^{a}$ Dra $^{\mathrm{a}}$, Departamento de Zootecnia, Faculdade de Medicina Veterinária e Zootecnia, UFMS, Campo Grande, MS, Brasil. E-mail: morais.mariazinha@gmail.com

4 Prof. Dr., Departamento de Zootecnia, Universidade Estadual de Mato Grosso do Sul, UEMS, Aquidauana, MS, Brasil. E-mail: henrique.uems@hotmail.com

5 Pesquisador, Empresa Brasileira de Pesquisa Agropecuária, EMBRAPA Gado de Corte, Campo Grande, MS, Brasil. E-mail: gelson.feijo@embrapa.br
}

* Author for correspondence 


\title{
Resumo
}

\begin{abstract}
Objetivou-se avaliar o desempenho, as características de carcaça e os componentes não-carcaça de cordeiros mestiços Texel confinados de diferentes classes de consumo alimentar residual (CAR). Foram confinados individualmente 47 cordeiros mestiços Texel (3/4 Texel + 1/4 Pantaneira), machos, não castrados, com peso médio inicial de $29,9 \pm 5,5 \mathrm{~kg}$ e idade de aproximadamente 4 meses. O consumo de matéria seca e ganho médio diário foram avaliados durante 70 dias. A dieta continha silagem de milho como volumoso e o concentrado consistia em milho grão, farelo de soja, ureia e mistura mineral, com relação volumoso: concentrado 60:40 e 72,35\% de nutrientes digestíveis totais. Após 70 dias de confinamento os cordeiros foram abatidos para avaliação das carcaça e componentes não-carcaças. Baseado no consumo alimentar residual (CAR) calculado, os cordeiros foram divididos em três classes de acordo com o desvio padrão: CAR Positivo (ineficientes, acima de 0,5 desvio padrão), CAR Negativo (eficientes, abaixo de 0,5 desvio padrão) e CAR Médio (intermediários). As classes com CAR Negativo (eficientes) e CAR Positivo (ineficientes) não apresentaram diferenças entre as médias de GMD $(0,321$ vs $0,306 \mathrm{~kg} ; \mathrm{P}>0,05)$. $\mathrm{O}$ consumo de matéria seca, expresso em $\mathrm{g} \mathrm{d}^{-1} \mathrm{e}$ em percentagem do peso vivo diferiram entre as classes $(\mathrm{P}<0,05)$. Os cordeiros eficientes (CAR Negativo) apresentaram redução de 9\% no CMS e o mesmo GMD em relação aos cordeiros ineficientes (CAR Positivo). Os cordeiros das classes de CAR Positivo e Negativo não apresentaram diferenças entre os pesos dos componentes nãocarcaça $(P>0,05)$. Não foram observadas alterações entre as classes de CAR quanto ao peso corporal em jejum, peso e rendimento de carcaça quente e pesos dos cortes comerciais $(P>0,05)$. A melhoria na eficiência alimentar pelo CAR não compromete o desempenho e as características de carcaça de cordeiros mestiços Texel.
\end{abstract}

Palavras-chave: Confinamento. Depósitos de gordura. Eficiência alimentar. Cortes cárneos. Ovinos.

\section{Introduction}

Lamb production through feedlot finishing is one of the main procedures to shorten slaughtering age and ensure high-quality prime cuts. In addition to intensive farming, the use of pure and crossbreed Texels has stood out in meat production because of these lambs' rustic nature, high weight gain, and early carcass finishing (FURUSHO-GARCIA et al., 2004). Identification of lambs that efficiently convert feed into weight gain is important to reduce feeding expenses and avoid food wastage in the feedlot.

This identification is achieved by determining feed efficiency (FE) and feed conversion (FC) indices that show a direct relationship between feed intake and weight gain. Although FE and FC allow identification of animals with low food demand and satisfactory development, these parameters of efficiency are also strongly associated with weight gain and body weight. As such, their use is limited, given that in the long-run, fast-growing animals may produce herds with larger adults (ARTHUR et al., 2001), which is undesirable from an economic perspective because large animals have higher food demand and nutritional requirements (NRC, 2007). Residual feed intake (RFI) index, calculated as the difference between observed and estimated feed intake (KOCH et al., 1963), is an alternative indicator of feed efficiency that has the advantage of being independent of growth parameters.

A negative RFI indicates lower observed than estimated feed intake (efficient animals); positive RFI corresponds to higher observed than estimated feed intake (inefficient animals), and intermediate RFI values are classified between these two observations (intermediate animals). RFI allows identification of individuals that exhibit lower feed intake and similar weight gain as that in inefficient animals. Despite the benefits of RFI as a measurement of feed efficiency that may potentially help reduce feed supply, weight gain composition can be variable. Efficient animals tend to have lesser fat deposits and are finished with low-fat carcasses - a condition that may compromise meat quality and conservation (GOMES et al., 2012; REDDEN et al., 2013; NASCIMENTO et al., 2016). Most 
results available in this regard are, however, based on cattle RFI, and data on sheep are scarce in national and international studies.

The present study aimed to assess the performance, carcass traits, and non-carcass components of feedlot finished Texel crossbred lambs from different RFI classes.

\section{Material and Methods}

The experiment was conducted at the Animal Metabolism Laboratory of the Universidade Federal Mato Grosso do Sul (UFMS) at the Faculty of Veterinary Medicine and Animal Science in Campo Grande, Mato Grosso do Sul state, Brazil, between August and December 2015. The experiment was carried out after approval by the UFMS Ethics Committee on Animal Use (file \# 631/2014). The care and use of lambs were performed according to the standards for animal experiments.

Forty-seven uncastrated male Texel crossbred lambs $(3 / 4$ Texel $+1 / 4$ Pantaneira $)$ tested here were 2 - to 4-month-old with a mean initial weight of $29.9 \pm 5.5$ $\mathrm{kg}$. They were identified and randomly distributed into $2.5 \mathrm{~m}^{2}$ individual pens with a suspended trough. The lambs were allowed to adapt to the diet and environment for 28 days. At the beginning of the experiment, the animals were weighed and treated against ectoparasites and endoparasites $\left(\right.$ Closantel $^{\circledR}$, Cidectin $^{\circledR}$, and Baycox ${ }^{\circledR}$ ). During the 28 days of adaptation, each animal was provided with corn silage along with a gradual increase in the dosage of concentrate until the level set for each diet was reached.

The lambs were confined for 70 days for individual feed intake assessment. The animals were fed twice a day: at 7:30 A.M. and 2:30 P.M. ( $50 \%$ of the total feed in the morning and $50 \%$ in the afternoon). The feed supplied to each animal was adjusted daily according to food refusals, which were kept at $100 \mathrm{~g} \mathrm{~kg}^{-1}$, to assure voluntary consumption. The diet (40:60 roughage to concentrate ratio) was formulated according to the guidelines of NRC (2007) for a weight gain of $200 \mathrm{~g} \mathrm{~d}^{-1}$ (Table 1).

Table 1. Ingredients and composition of experimental diet.

\begin{tabular}{lc}
\hline Ingredients $\left(\mathrm{g} \mathrm{kg}^{-1}\right)$ & Total Diet \\
\hline Corn Silage & 400,00 \\
Ground corn grain & 38,94 \\
Soybean & 16,80 \\
Mineral premix & 9,00 \\
Urea & 3,00 \\
Complements (milk aroma) & 3,60 \\
\hline Components $\left(\mathrm{g} \mathrm{kg}^{-1}\right)$ & Forage:concetrate ratio $(60: 40)$ \\
\hline Dry matter & 55,30 \\
Crude protein & 15,40 \\
Ash & 5,27 \\
Ether extract & 3,08 \\
Neutral detergent fiber corret to protein & 24,65 \\
Acid detergent fiber corret to protein & 12,04 \\
Non-fibrous carbohydrates & 1 \\
Total Digestible Nutrients & 52,74 \\
\hline
\end{tabular}

${ }^{1}$ Estimated by equation of Hall (2000): NFC $=100-[(\mathrm{CP}-\mathrm{CP}$ derived from urea + urea $)+\mathrm{NDFp}+\mathrm{EE}+\mathrm{ash}]$. 
Corn silage was used in the form of roughage, while the concentrate consisted of corn grain, soybean meal, urea, and mineral mixture. Samples of the diet and refusals were collected every 14 days, identified, and frozen for subsequent analysis. Chemical analyses of the diets were performed at the Laboratory of Animal Nutrition (FAMEZ/ UFMS) according to AOAC protocols (1995) for dry matter (967.03), crude protein (981.10), mineral matter (942.05), and ether extract (920.29).

The Van Soest method (1991) was applied to determine neutral detergent fiber (NDF), acid detergent fiber (ADF), and lignin; values of NDF and $\mathrm{ADF}$, after correction for crude protein, were also determined (NDFcp and ADFcp, respectively). Non-fiber carbohydrates (NFC) were determined according to the method of Sniffen et al. (1992), using the equation $\mathrm{NFC}=100-(\mathrm{CP}+\mathrm{MM}+\mathrm{NDF} p$ $+\mathrm{EE})$. Total digestible nutrient (TDN) levels in the silage were estimated using the equation proposed by Cappelle et al. (2001), which considers NDF.

The animals were weighed after a $16-\mathrm{h}$ fast at the onset and end of the growing phase (70 days of feedlot time) to obtain initial and final body weight (BWi and BWf). Average daily gain (ADG) was calculated from the weight of unfasted lambs that was recorded every 14 days. After being confined for 70 days, the lambs were weighed to obtain shrunk body weight (SBW). Animals were stunned with a stun bolt gun, bled by cutting the carotid artery and jugular vein, skinned, and eviscerated. The amount of blood collected, as well as weight of head and legs was recorded along with the weight of skin, wool, and other external components (testicles and tail).

After evisceration, non-carcass components, including organs (tongue + trachea + esophagus, heart, lungs, spleen, liver + gallbladder + diaphragm, kidneys, and reproductive + urinary tract), the gastrointestinal tract (rumen, omasum, reticulum, and abomasum, small and large intestine), and deposits of visceral fat (omental, mesenteric, perirenal, inguinal, and cardiac) were extracted. The gastrointestinal components were weighed when full, followed by weighing after being emptied, washed, and emptied again to determine weight of empty gastrointestinal tract.

Carcasses were divided into two halves, and hot carcass weights (HCW) were measured immediately. The HCW were used to determine hot dressing (HD $\left.=\mathrm{HCW} / \mathrm{SBW}^{*} 100\right)$. After carcasses had been kept in a cold chamber at $-4^{\circ} \mathrm{C}$ for $24 \mathrm{~h}$, the internal length of the carcass (from the center of the anterior border of the pubic arch to the anterior border of the first rib), external length (from the bottom of the tail to the bottom of the neck), maximum and minimum thoracic depth (maximum and minimum distances between carcass sternum and back), leg length (from the anterior border of the ischiopubic symphysis to the middle portion of the tarsal bones), and leg thickness were recorded. A crosssection between the 12 and $13^{\text {th }}$ ribs was cut out in the left-half of the carcass to measure subcutaneous fat thickness with a caliper rule. The right-half of the carcass was divided into 8 cuts (neck, shoulder + shank, loin, rack, flank steak, rack cap off, leg, and HH section) (Hankins and Howe, 1946), which were then individually weighed.

Individual dry matter intake (DMI, in $\mathrm{kg} \mathrm{d}^{-1}$ ) was calculated as the difference between DM offered and refused. Average daily gain (ADG, in $\mathrm{kg} \mathrm{d}^{-1}$ ) during the feed efficiency assessment period and over the entire experiment was estimated by performing regression analysis between BW and days on feed using PROC REG (SAS Institute, 2009), where the slope represents the growth rate. The mid-test of metabolic body weight (MMBW) was calculated as the mean of BWi and BWf.

The feeding efficiency indexes calculated here were feed conversion $\left[\mathrm{FC}=\mathrm{DMI}\left(\mathrm{g} \mathrm{d}^{-1}\right) / \mathrm{ADG}\right.$ $\left.\left(\mathrm{g} \mathrm{d}^{-1}\right)\right]$, feed efficiency $\left[\mathrm{FE}=\mathrm{ADG}\left(\mathrm{g} \mathrm{d}^{-1}\right) / \mathrm{DMI}\right.$ $\left.\left(\mathrm{g} \mathrm{d}^{-1}\right)\right]$, and residual feed intake $\left[\mathrm{RFI}=\left(\mathrm{DMI}_{\mathrm{obs}}\right.\right.$ - DMI $_{\text {est }}$ ] according to the method of Koch et al. (1963). Observed DMI (DMI ${ }_{\text {obs }}$ ) corresponded 
to DM differences between total diet offered and refusals. Estimated DMI $\left(\mathrm{DMI}_{\text {est }}\right)$ was obtained by performing regression on $\mathrm{DMI}_{\text {obs }}$ as a function of metabolic body weight $\left[\mathrm{MMBW}^{0.75}=(\mathrm{BWi}\right.$ $+\mathrm{BWf}) / 2]^{0.75}$ and $\mathrm{ADG}$, where $\mathrm{DMI} \mathrm{est}=\beta_{0}+\beta_{1} \times$ $\left(\mathrm{MMBW}^{0.75}\right)+\beta_{2} \times(\mathrm{ADG})+\varepsilon$. Data were analyzed using the REG procedure (SAS, 2009).

Based on the RFI calculated, the lambs were divided into three classes according to the standard deviation (sd): Positive RFI (inefficient, 0.5 above the mean), Negative RFI (efficient, 0.5 below the mean), and Medium RFI (intermediate). Data were subjected to analysis of variance and the means were compared by the Tukey's test $(\alpha=0.05)$ using the GLM procedure of SAS (SAS, 2009).

\section{Results and Discussion}

Among the lambstested, $23.40 \%$ had Negative RFI (efficient), 42.55\% had average RFI (intermediate), and $34.04 \%$ had Positive RFI (inefficient). The mean RFI recorded here was $0.00 \pm 0.084 \mathrm{~kg} \mathrm{~d}^{-1}$, ranging from -0.239 to +0.169 . Values of BWi, BWf, mean $\mathrm{BW}$, and $\mathrm{PCM}^{0.75}$ did not differ between the three RFI classes (Table 2). The classes with Negative RFI (efficient) and Positive RFI (inefficient) showed no differences in $\mathrm{ADG}(\mathrm{P}>0.05)$.

Table 2. Performance of Texel crossbred lambs from different residual feed intake classes.

\begin{tabular}{|c|c|c|c|c|c|}
\hline \multirow[b]{2}{*}{ Traits } & \multicolumn{3}{|c|}{ Residual feed intake $^{1}$} & \multirow[b]{2}{*}{$\mathrm{CV}(\%)^{2}$} & \multirow[b]{2}{*}{ P-value } \\
\hline & $\begin{array}{l}\text { Negative } \\
\text { (Efficient) }\end{array}$ & $\begin{array}{c}\text { Medium } \\
\text { (Intermediate) }\end{array}$ & $\begin{array}{c}\text { Positive } \\
\text { (Inefficient) }\end{array}$ & & \\
\hline $\mathrm{N}$ & 11 & 20 & 16 & - & - \\
\hline BWi (kg) & 28.82 & 30.25 & 30.23 & 18.69 & 0.763 \\
\hline BWf $(\mathrm{kg})$ & 51.16 & 49.37 & 51.57 & 12.97 & 0.571 \\
\hline MMBW (kg) & 40.06 & 39.82 & 41.32 & 15.11 & 0.748 \\
\hline $\mathrm{MBW}^{0.75}(\mathrm{~kg})$ & 15.44 & 15.28 & 15.56 & 10.77 & 0.877 \\
\hline $\operatorname{ADG}\left(\mathrm{kg} \mathrm{d}^{-1}\right)$ & $0.321^{\mathrm{a}}$ & $0.277^{\mathrm{b}}$ & $0.306^{\mathrm{ab}}$ & 13.93 & 0.017 \\
\hline $\operatorname{DMI}\left(\mathrm{kg} \mathrm{d}^{-1}\right)$ & $1.34^{\mathrm{b}}$ & $1.35^{\mathrm{b}}$ & $1.52^{\mathrm{a}}$ & 15.87 & 0.050 \\
\hline DMI ( $\left.\mathrm{g} \mathrm{kg}^{-1} \mathrm{BW}\right)$ & $33.5^{\mathrm{b}}$ & $34.1^{\mathrm{b}}$ & $36.8^{\mathrm{a}}$ & 7.08 & 0.001 \\
\hline TDNI $\left(\mathrm{g} \mathrm{kg}^{-1} \mathrm{BW}\right)$ & $26.0^{\mathrm{b}}$ & $26.4^{\mathrm{b}}$ & $28.5^{\mathrm{a}}$ & 7.08 & 0.002 \\
\hline FE & $0.24^{\mathrm{a}}$ & $0.21^{\mathrm{b}}$ & $0.20^{\mathrm{b}}$ & 12.82 & 0.001 \\
\hline $\mathrm{FC}$ & $4.18^{\mathrm{a}}$ & $4.90^{\mathrm{b}}$ & $5.00^{\mathrm{b}}$ & 12.91 & 0.003 \\
\hline RFI & $-0.120^{\mathrm{a}}$ & $0.002^{\mathrm{b}}$ & $0.079^{c}$ & 9.34 & $<0.001$ \\
\hline
\end{tabular}

${ }^{1}$ Different letters indicate statistical difference between the classes (Tukey, $\mathrm{P}<0.05$ ). ${ }^{2} \mathrm{CV}$ : coefficient variation $\mathrm{BWi}=$ initial body weight, $\mathrm{BWf}=$ final body weight, $\mathrm{MMBW}=$ mid-test metabolic body weight mean body weight, $\mathrm{MBW}^{0.75}=$ metabolic body weight, $\mathrm{ADG}=$ average weight gain, $\mathrm{DMI}=$ dry matter intake; TDNI = total digestible nutrient intake; FE = feed efficiency; $\mathrm{FC}=$ feed conversion; RFI = residual feed intake.

These results were expected because RFI does not depend on MMBW ${ }^{0.75}$ or ADG (MURO-REYES et al., 2011; SOBRINHO et al., 2011; COCKRUM et al., 2013), which are the parameters generally adopted to predict feed intake (KOCH et al., 1963). It has been shown previously that BWf and ADG are usually similar between RFI classes (PAULA et al., 2013; REDDEN et al., 2013a,b), but DMI is lower in more efficient animals. The lack of correlation with performance parameters (ADG and $\mathrm{BW}$ ) suggests that RFI allows the identification of animals with higher feed conversion efficiency, which, interestingly, does not correspond to larger adults (REDDEN et al., 2011). 
Here, ADG was lower in intermediate class lambs (average RFI) than in their inefficient counterparts (Positive RFI) $(\mathrm{P}<0.05)$. Most studies report the absence of phenotypic correlations between weight gain, live weight, and RFI, that is, weight is usually similar between the RFI classes. Data on cattle, however, are inconsistent. In a study on calves subjected to two feedlot trials, Jensen et al. (1992) found a positive genetic correlation followed by a negative one between weight gain and RFI ( $r=0.32$ in the first and $r=-0.24$ in the second trial).

Arthur et al. (2001a) observed a negative correlation between weight gain and RFI ( $\mathrm{r}=$ -0.10) for Charolais bulls. Archer et al. (1998) recorded a negative correlation between weight gain and RFI $(\mathrm{r}=-0.25)$ for Angus bulls and heifers in feedlots as well. However, a positive genetic correlation between RFI and live weight $(r=0.32)$ was reported for Charolais bulls (ARTHUR et al., 2001b). According to these studies, weight gain and RFI are not completely genetically independent; furthermore, many parameters, other than weight and weight gain, can be used to adjust RFI (e.g., body composition).

The diets used here were formulated according to the average nutritional needs of precocious and non-precocious lambs recommended by the NRC (2007). The high-quality of lambs allowed them to express their potential ADG, which was higher than expected $\left(200 \mathrm{~g} \mathrm{~d}^{-1}\right)$. The intake of DM and TDN, expressed as $\mathrm{gd}^{-1}$ and percentage of $\mathrm{BW}$, respectively, differed between the RFI classes ( $\mathrm{P}<0.05$; Table 2$)$. Lambs with Negative and Intermediate RFI values showed lower DMI and total digestible nutrient intake (TDNI) than those with Positive RFI $(\mathrm{P}<$ $0.05)$. As compared to the class of inefficient lambs, the efficient class (negative RFI) showed a 9\% reduction in DMI, while having the same ADG.

Redden et al. (2011) found a similar weight gain between ewes with Positive and Negative RFI values, but the latter (efficient class) showed a $20 \%$ reduction in FE. Other studies corroborate this finding; there has been a report of 15 to $30 \%$ reduction in DMI in animals classified as efficient (MURO-REYES et al., 2011; REDDEN et al., 2013b). Cockrum et al. (2013) classified 15\% of the sheep in their sample to have Positive RFI and another $15 \%$ to have Negative RFI; they also observed an FI reduction of approximately 1.2 $\mathrm{kg} \mathrm{d}^{-1}$ in the most efficient individuals. Similar ADG between the RFI classes in combination with a decline in DMI (\% BW) contributed to the improvement in FC and FE $(\mathrm{P}<0.05)$.

The results of the present study corroborate previous studies on RFI-based assessment of FE in lambs (MURO-REYES et al., 2011; COCKRUM et al., 2013; PAULA et al., 2013; REDDEN et al., 2013b). Lambs with Negative RFI showed higher $\mathrm{FE}$ and lower $\mathrm{FC}$ in relation to other classes $(\mathrm{P}<$ $0.05)$ that exhibited no differences $(P>0.05)$. In addition, $\mathrm{FC}$ in efficient animals (negative RFI) was $16.4 \%$ lower, and FE was $20.0 \%$ higher than in the lambs with Medium and Positive RFI.

Variations in DMI and FE between animals from different RFI classes have been associated with several biological processes and environmental factors that regulate feeding and growth. Richardson et al. (2004) and Herd and Arthur (2009) reported that the main processes underlying variations in FE are feeding patterns (2\%), digestibility (10\%), heat increment and fermentation (9\%), physical activity (10\%), protein turnover, tissue metabolism and stress (at least 37\%), body composition (5\%), ion transport, and other unknown processes (27\%). Aspects related to feeding behavior that were not evaluated in the present study may have contributed to a decrease in FI and an increase in FE in the lambs with Negative RFI. According to Sharifabadi et al. (2016), efficient animals spend less time ingesting and ruminating food. The authors argue that the longer an animal performs these activities, the higher is its energy expenditure in terms of metabolizable energy for maintenance; this might, in turn, decrease energy efficiency, and thus, reduce the energy available for growth. 
Differences in the metabolic rates and changes in organ and viscera size can affect lamb FE. Although the gastrointestinal tract and liver represent a small fraction of BW (10 to $13 \%$ ), they consume 45 to $50 \%$ of the maintenance energy required for absorbing and metabolizing digested nutrients (SEAL; REYNOLDS, 1993). As such, size differences may contribute significantly to variations in oxygen consumption and energy expenditure on animal maintenance (REYNOLDS, 2002). In the present study, however, Positive and Negative RFI classes did not show significant weight differences between the non-carcass components (external components and organs and empty gastrointestinal tract) $(\mathrm{P}>$ 0.05 ; Table 3).

Table 3. Weight of non-carcass components $(\mathrm{kg})$ of crossbred Texel lambs from different residual feed intake classes.

\begin{tabular}{|c|c|c|c|c|c|}
\hline \multirow[b]{2}{*}{ Traits } & \multicolumn{3}{|c|}{ Residual Feed Intake $^{1}$} & \multirow[b]{2}{*}{$\mathrm{CV}(\%)^{2}$} & \multirow[b]{2}{*}{ P-value } \\
\hline & $\begin{array}{l}\text { Negative } \\
\text { (Efficient) }\end{array}$ & $\begin{array}{c}\text { Medium } \\
\text { (Intermediate) }\end{array}$ & $\begin{array}{c}\text { Positive } \\
\text { (Inefficient) }\end{array}$ & & \\
\hline \multicolumn{6}{|l|}{ External components } \\
\hline Head & 2.44 & 2.30 & 2.45 & 10.84 & 0.182 \\
\hline Wool and skin & 6.22 & 5.61 & 5.74 & 21.57 & 0.425 \\
\hline Feet & 1.12 & 1.06 & 1.11 & 12.17 & 0.312 \\
\hline Tail & 0.32 & 0.26 & 0.29 & 36.81 & 0.414 \\
\hline Testicles & 0.65 & 0.67 & 0.67 & 21.08 & 0.916 \\
\hline Blood & 1.94 & 1.93 & 1.96 & 15.59 & 0.962 \\
\hline \multicolumn{6}{|l|}{ Organs } \\
\hline Tongue, trachea, esophagus & 0.62 & 0.59 & 0.60 & 16.05 & 0.714 \\
\hline Heart & 0.18 & 0.18 & 0.20 & 17.33 & 0.104 \\
\hline Lungs & 0.44 & 0.42 & 0.47 & 15.11 & 0.133 \\
\hline Spleen & 0.08 & 0.08 & 0.09 & 19.34 & 0.320 \\
\hline Liver, gallbladder and diaphragm & $0.95^{\mathrm{ab}}$ & $0.86^{\mathrm{b}}$ & $0.98^{\mathrm{a}}$ & 15.25 & 0.029 \\
\hline Kidneys & 0.12 & 0.11 & 0.12 & 17.08 & 0.142 \\
\hline Reproductive and urinary system & 0.13 & 0.12 & 0.14 & 39.63 & 0.474 \\
\hline \multicolumn{6}{|l|}{ Gastrointestinal tract } \\
\hline Stomach & 1.37 & 1.28 & 1.31 & 14.56 & 0.462 \\
\hline Small intestine & $0.65^{\mathrm{a}}$ & $0.53^{\mathrm{b}}$ & $0.64^{\mathrm{a}}$ & 17.83 & 0.002 \\
\hline Large intestine & $0.35^{\mathrm{a}}$ & $0.30^{\mathrm{b}}$ & $0.36^{\mathrm{a}}$ & 18.08 & 0.022 \\
\hline
\end{tabular}

${ }^{1}$ Different letters indicate statistical difference between the classes (Tukey, $\mathrm{P}<0.05$ ). ${ }^{2} \mathrm{CV}$ : coefficient variation.

Several studies report that animals from different RFI classes do not differ with respect to the weight of gastrointestinal tissues and internal organs (RICHARDSON et al., 2001; CRUZ et al., 2010; BONILHA et al., 2013). In our study, we observed the weight of the small and large intestine to be lower in the animals with average RFI (intermediate) than those from other classes $(\mathrm{P}<005)$; average liver weight was also lower in this class than in the lambs with positive RFI $(\mathrm{P}<0.05$; Table 3$)$.

The lower weight of organs in lambs from the intermediate class may be associated with their slower growth that is indicated by reduced ADG (Table 2). Given that no weight difference was found between the non-carcass components of the 
different classes, the improvement in FE of lambs with negative RFI may be related to metabolic processes, such as digestion, intestinal absorption, levels of circulating hormones and metabolites, and oxygen consumption in tissue synthesis and degradation, although these parameters were not assessed in the present study.

Magnani et al. (2013) investigated diet digestibility in Nellore heifers in feedlots and found that Negative RFI heifers had higher apparent digestibility of DM (49.14\% versus $45.38 \%$ ), NDF (56.65\% versus $49.88 \%)$, ADF (49.96\% versus $45.08 \%$ ), and cellulose (61.61\% versus $56.40 \%)$ as compared to animals with Positive RFI. Sharma et al. (2016) found efficient animals (negative RFI calves) to have higher $(p<0.05)$ levels of growth hormones in plasma, insulin-like growth factor-1 (IGF-1) and triiodothyronine $\left(\mathrm{T}_{3}\right)$, and a lower concentration of thyroxin hormone. According to the authors, several genes responsible for decrease in blood IGF-I are associated with Negative RFI (efficient), which shows heritability (0.40) of this hormone.

Another possible source of FE variation may be associated with visceral fat deposition (REDDEN et al., 2013b). Animals classified as efficient according to their RFI show leaner body composition with better muscle deposition and lower fat accumulation in the internal organs (GOMES et al., 2012; NASCIMENTO et al., 2016). However, no differences in cardiac, omental, mesenteric, perirenal, or inguinal fat deposition were detected between the RFI classes (Table 4; P $>0.05$ ). These results corroborate findings of other studies on the FE of confined cattle, which also found no differences in visceral fat between the three RFI classes (BAKER et al., 2006; ARTHUR et al., 2008; CRUZ et al., 2010).

Table 4. Weight of fat deposits (kg) of crossbred Texel lambs from different residual feed intake classes.

\begin{tabular}{lccccc}
\hline \multirow{2}{*}{ Traits } & \multicolumn{3}{c}{ Residual Feed Intake $^{1}$} & CV (\%) & P-value \\
\cline { 2 - 4 } & $\begin{array}{c}\text { Negative } \\
\text { (Efficient) }\end{array}$ & $\begin{array}{c}\text { Medium } \\
\text { (Intermediate) }\end{array}$ & $\begin{array}{c}\text { Positive } \\
\text { (Inefficient) }\end{array}$ & & \\
\hline Cardiac & 0.14 & 0.12 & 0.13 & 34.50 & 0.530 \\
Omental & 1.07 & 0.96 & 1.14 & 28.40 & 0.208 \\
Mesenteric & 0.65 & 0.67 & 0.72 & 31.32 & 0.710 \\
Perirenal & 0.80 & 0.68 & 0.81 & 43.61 & 0.450 \\
Inguinal & 0.38 & 0.44 & 0.43 & 36.19 & 0.610 \\
\hline
\end{tabular}

${ }^{1}$ Different letters indicate statistical difference between the classes (Tukey, $\mathrm{P}<0.05$ ). ${ }^{2} \mathrm{CV}$ : coefficient variation.

In the present study, fat deposition corresponded, on average, to $5.68 \mathrm{~kg} / 100 \mathrm{~kg}$ of SBW, which is much higher than the $4.12 \mathrm{~kg} / 100 \mathrm{~kg}$ SBW observed previously by Ribeiro et al. (2009) in Texel crossbred lambs. The similarities between the different classes in relation to fat deposition likely resulted from the advanced physiological conditions of the animals that were slaughtered at a BW of $50 \mathrm{~kg}$. In fact, Texel lambs reach maturity at nearly $37 \mathrm{~kg} \mathrm{BW}$ (MALHADO et al., 2008).
The long adaptation period ( 28 days) needed for helminth control and feeding adjustments, in conjunction with the 70 days required for accurate RFI assessment (ARCHER; BERGH, 2000; WANG et al., 2006; CASTILHOS et al., 2011), contributed to the heaviness and maturity of lambs at the time of slaughter.

Similar to the present study (Table 3), Sanches et al. (2006) found no differences between RFI 
classes in terms of backfat, as well as intramuscular and visceral fat, but they observed that animals with negative RFI (efficient) showed higher levels of leptin in plasma. According to these authors, the high leptin levels inhibited appetite of efficient animals, thereby decreasing their food intake. Richardson et al. (2001) attribute differences in energy efficiency between classes to reductions in oxygen uptake in the tissues, given that this index is strongly associated with feed intake.

The RFI classes showed no differences in SBW, HCW, and HD (Table 5). Mean SBW (49.35 kg) and
HCW (24.14 kg) were satisfactory for uncastrated male lambs $(3 / 4$ Texel $+1 / 4$ Pantaneira $)$ that were slaughtered when they were 200-day-old. The values obtained for these parameters are higher than those reported by Carvalho et al. (2007) for castrated male Texel lambs slaughtered at the $144^{\text {th }}$ day and had reached SBW of $33.9 \mathrm{~kg}$ and HCW of 15.1 $\mathrm{kg}$. In an assessment of the carcass traits of Dorper lambs, Grobe et al. (2014) also report no differences between negative and positive RFI animals in terms of SBW, carcass weight, and HD.

Table 5. Carcass traits and morphometric measurements of crossbred Texel lambs from different residual feed intake classes.

\begin{tabular}{lccccc}
\hline \multirow{2}{*}{ Traits } & \multicolumn{3}{c}{ Residual Feed Intake $^{1}$} & & \\
\cline { 2 - 4 } & $\begin{array}{c}\text { Negative } \\
\text { (Efficient) }\end{array}$ & $\begin{array}{c}\text { Medium } \\
\text { (Intermediate) }\end{array}$ & $\begin{array}{c}\text { Positive } \\
\text { (Inefficient) }\end{array}$ & CV (\%) & P-value \\
\hline BWS, kg & 50.39 & 47.73 & 49.94 & 12.49 & 0.416 \\
HCW, kg & 24.64 & 23.81 & 23.98 & 14.08 & 0.803 \\
HD, kg 100 & 48.85 & 49.79 & 48.03 & 27.93 & 0.062 \\
ILC, cm & 66.77 & 65.25 & 65.75 & 5.11 & 0.489 \\
ELC, cm & 86.27 & 84.52 & 86.12 & 5.15 & 0.446 \\
TDmax, cm & 22.09 & 21.88 & 22.23 & 5.78 & 0.711 \\
TDmin, cm & 18.95 & 18.58 & 18.81 & 5.87 & 0.629 \\
LL, cm & 37.36 & 36.48 & 37.16 & 5.76 & 0.467 \\
LT, cm & 10.64 & 10.75 & 10.65 & 9.63 & 0.944 \\
SFT, mm & 4.89 & 4.59 & 4.76 & 27.04 & 0.819 \\
\hline
\end{tabular}

${ }^{1}$ Different letters indicate statistical difference between the classes (Tukey, $\mathrm{P}<0.05$ ). ${ }^{2} \mathrm{CV}$ : coefficient variation $\mathrm{BWS}=$ body weight at slaughter $(\mathrm{kg})$; HCW = hot carcass weight $(\mathrm{kg}) ; \mathrm{HD}=$ hot dressing $(\mathrm{kg} 100 \mathrm{~kg})$; ILC= internal length of the carcass $(\mathrm{cm}) ; \mathrm{ELC}=$ external length of the carcass $(\mathrm{cm})$; TDmax $=$ maximum thoracic depth $(\mathrm{cm})$; PTmin = minimum thoracic depth $(\mathrm{cm}) ; \mathrm{LL}=$ leg lenght $(\mathrm{cm}) ; \mathrm{LT}=$ leg thickness $(\mathrm{cm}) ; \mathrm{SFT}=$ subcutaneous fat thickness $(\mathrm{mm})$.

In the present study, HD was higher than that reported in other studies on Texel crossbred lambs, which achieved an average of $40 \mathrm{~kg} / 100$ $\mathrm{kg}$ (LANDIM et al., 2007; VILLARROEL et al., 2006). The average HD observed here $(49.4 \%)$ is within the range of 40 to $50 \%$, which is considered satisfactory for breeds, such as Texel, that are farmed specifically for meat production. Although normal, the results obtained for Texel crossbred lambs are slightly lower than those observed for other breeds, such as Santa Inês, a non-wool breed. Carcass yield is an important parameter since it represents the profitability of the edible portion of the animal (PASCOAL et al., 2010).

Average SFT was similar between the RFI classes $(P>0.05)$, i.e., carcass finishing was not affected by the higher efficiency of the animals. These results 
corroborate earlier studies that found no differences in the SFT of animals from different RFI-based efficiency classes (PAULA et al., 2013; REDDEN et al., 2013a,b). The animals showed an average of $4.75 \mathrm{~mm}$ SFT, which is within the range expected for average SBW (50 kg) and is sufficient to ensure carcass filling and protection against chilling losses and muscle fiber shortening in the cold chamber. Redden et al. (2013b) observed similar SFT, from 4.4 to $4.8 \mathrm{~mm}$, in lambs weighing approximately 57 $\mathrm{kg}$, which is within the limits for adequate finishing (3 to $5 \mathrm{~mm}$ ).

Mean internal carcass length $(\mathrm{cm})$, external carcass length $(\mathrm{cm})$, thoracic depth $(\mathrm{cm})$, and leg length $(\mathrm{cm})$ were similar between the RFI classes $(P>0.05$; Table 5). This result was expected given that carcass measurements are associated with growth traits, such as body weight, that did not differ between the RFI classes (Table 2). Similarly, Basarab et al. (2003) did not find differences between morphometric measurements evaluated in the carcasses of beef cattle from different RFI classes.

Morphometric variables are important to obtain information about the carcass components and support evaluation systems for sheep carcass classification introduced by the European Union and United States Department of Agriculture USDA. A sheep evaluation system is yet to be developed in Brazil, and research in this field is still incipient. Ricardo et al. (2016) evaluated the carcass morphometry of 252 sheep that were less than 12-month-old and were commercially slaughtered in Brazil after being classified according to the European carcass classification model.

The authors considered the lambs with excellent conformation (U grade) to be those with 44.23 $\mathrm{kg}$ SBW, $3.04 \mathrm{BCS}, 25.68 \mathrm{~cm}$ maximum thoracic depth, $39 \mathrm{~cm} \mathrm{leg} \mathrm{length,} \mathrm{and} 68.08 \mathrm{~cm}$ external carcass length. Except for the external carcass length $(\mathrm{cm})$, similar values were obtained for lambs that were evaluated in the present study (49.35 SBW, 4.2 BCS, $22.06 \mathrm{~cm}$ maximum thoracic depth, $37 \mathrm{~cm}$ leg length, and $85.63 \mathrm{~cm}$ external carcass length). As such, their classification corresponds to good conformation according to the European system of sheep carcass evaluation. These data encouraged us to infer that irrespective of RFI class, the Texel crossbred lamb carcasses exhibit superior conformation, and thus, add value to the animal for exportation purposes.

The RFI classes showed no differences in the neck, shoulder + shank, loin, rack, flank steak, rack cap off, leg, and $\mathrm{HH}$ section weight $(\mathrm{P}>0.05$, Table 6). Accordingly, a number of studies found no differences in the weight of beef cut from cattle in different RFI classes (GOMES et al., 2012; REIS et al., 2015; NASCIMENTO et al., 2016). This result was expected because the carcasses from the three efficiency classes exhibited similar weight and morphometric measures (Table 4).

Table 6. Weight commercial cuts $(\mathrm{kg})$ of crossbred Texel lambs from different residual feed intake classes.

\begin{tabular}{lccccc}
\hline \multirow{2}{*}{ Traits } & \multicolumn{3}{c}{ Residual Feed Intake } & & PV (\%) \\
\cline { 2 - 4 } & $\begin{array}{c}\text { Negative } \\
\text { (Efficient) }\end{array}$ & $\begin{array}{c}\text { Medium } \\
\text { (Intermediate) }\end{array}$ & $\begin{array}{c}\text { Positive } \\
\text { (Inefficient) }\end{array}$ & P-value \\
\hline Shoulder+shank & 2.22 & 2.07 & 2.21 & 14.61 & 0.308 \\
Leg & 3.64 & 3.53 & 3.58 & 12.89 & 0.814 \\
Loin & 1.45 & 1.34 & 1.42 & 15.20 & 0.282 \\
Rack & 1.73 & 1.85 & 1.85 & 19.37 & 0.616 \\
& & & & & continue
\end{tabular}


continuation

\begin{tabular}{llllll} 
Flank steak & 0.55 & 0.57 & 0.56 & 30.61 & 0.938 \\
Rack cap off & 1.13 & 0.96 & 1.04 & 20.65 & 0.106 \\
Neck & 0.89 & 0.88 & 0.96 & 20.65 & 0.449 \\
HH section & 0.38 & 0.36 & 0.38 & 18.15 & 0.744 \\
\hline
\end{tabular}

${ }^{1}$ Different letters indicate statistical difference between the classes (Tukey, $\mathrm{P}<0.05$ ). ${ }^{2} \mathrm{CV}$ : coefficient variation.

Other studies show moderate to high correlations between biometric measurements and carcass characteristics, indicating association between body weight, carcass yield, and commercial sheep cuts (LANDIM et al., 2007; PINHEIRO; JORGE, 2010). The present work found an average neck weight of $0.91 \mathrm{~kg}$, shoulder + shank weight of 2.16 $\mathrm{kg}$, loin weight of $1.4 \mathrm{~kg}$, rack weight of $1.81 \mathrm{~kg}$, flank steak weight of $0.56 \mathrm{~kg}$, rack cap off weight of $1.04 \mathrm{~kg}$, leg weight of $3.58 \mathrm{~kg}$, and $\mathrm{HH}$ section weight of $0.37 \mathrm{~kg}$. Ricardo et al. (2016) recorded a weight of $3.37 \mathrm{~kg}$ for the leg, $1.41 \mathrm{~kg}$ for the loin, and $0.75 \mathrm{~kg}$ for loin chop, which is similar to that obtained in an present experiment. Furusho-Garcia et al. (2003) evaluated Texel crossbred lambs and recorded a leg weight of $3.30 \mathrm{~kg}$, rack weight of 1.98 $\mathrm{kg}$, and shoulder + shank weight of $1.99 \mathrm{~kg}$. As such, improvements in feed efficiency as a function of RFI do not compromise the weight of lamb meat cuts.

Improvement in feed efficiency as a function of the residual feed intake (RFI) index does not compromise performance and carcass traits in Texel crossbred lambs. Thus, RFI is an indicator of feeding efficiency that can support informed decisions to reduce feed inputs for lambs farmed on feedlots, thereby enhancing lamb meat production profits.

\section{Acknowledgments}

We thank the Conselho Nacional de Desenvolvimento Científico e Tecnológico (CNPq) and the Fundação de Apoio ao Desenvolvimento do Ensino, Ciência e Tecnologia from the state of Mato Grosso do Sul, Brazil, for their financial support. The Macal Animal Nutrition Company for donation of the concentrate supplement used in the experiment and the Empresa Brasileira de Pesquisa Agropecuária (Embrapa Beef Cattle) for providing the infrastructure and materials required to slaughter and process carcass.

\section{References}

ARCHER, J. A.; ARTHUR, P. F.; HERD, R. M.; RICHARDSON, E. C. Genetic variation in feed efficiency and its component traits. In: WORLD CONGRESS ON GENETICS APPLIED TO LIVESTOCK PRODUCTION, 25., 1998. Armidale. Proceedings... Armidale: World Congress on Genetics Applied to Livestock Production, 1998. p. 81-84.

ARCHER, J. A.; BERGH, L. Duration of performance tests for growth rate, feed intake and feed efficiency in four biological types of beef cattle. Livestock Production Science, Amsterdam, v. 65, n. 2, p. 47-55, 2000.

ARTHUR, P. F.; HERD, R. M. Residual feed intake in beef cattle. Revista Brasileira de Zootecnia, Viçosa, v. 37, p. 269-279, 2008. Supplement.

ARTHUR, P. F.; RENAND, G.; KRAUSS, D. Genetic and phenotypic relationships among different measures of growth and feed efficiency in young Charolais bulls. Livestock Production Science, Amsterdam, v. 68, n. 2-3, p. 131-139, 2001b.

ARTHUR, P. F; ARCHER, J. A.; HERD, R. M.; MELVILLE, G. J. Response to selection for net feed intake in beef cattle. In: ASSOCIATION FOR THE ADVANCEMENT OF ANIMAL BREEDING AND GENETICS, 14., 2001. Queenstown. Proceedings... Queenstown: Association for the advancement of Animal Breeding and Genetics, 2001a. p. 135-138.

ASSOCIATION OF OFFICIAL ANALYTICAL CHEMISTRY - AOAC. Official methods of analysis. $16^{\text {th }}$ ed. Arlington, VA: AOAC International, 1995. 
BAKER, S. D.; SZASZ, J. I.; KLEIN, T. A.; KUBER, P. S.; HUNT, C. W.; GLAZE JÚNIOR, J. B.; FALK, D.; RICHARD, R.; MILLER, J. C.; BATTAGLIA, R. A.; HILL, R. A. Residual feed intake of purebred Angus steers: Effects on meat quality and palatability. Journal of Animal Science, Savoy, v. 84, n. 4, p. 938-945, 2006.

BASARAB, J. A.; PRICE, M. A.; AALHUS, J. L.; OKINE, E. K.; SNELlinG, W. M.; LYLE, K. L. Residual feed intake and body composition in young growing cattle. Canadian Journal of Animal Science, Ottawa, v. 83, n. 2, p. 189-204, 2003.

BONILHA, E. F. M.; BRANCO, R. H.; BONILHA, S. F. M.; ARAUJO, F. L.; MAGNANI, E.; MERCADANTE, M. E. Z. Body chemical composition of Nellore bulls with different residual feed intake. Journal of Animal Science, Savoy, v. 91, n. 4, p. 3457-3464, 2013.

CAPPELlE, E. R.; VALADARES FILHO, S. C.; SILVA, J. F. C.; CECON, P. R. Estimativas do valor energético a partir de características químicas e bromatológicas dos alimentos. Revista Brasileira Zootecnia, Viçosa, v. 30, n. 6, p. 1837-1856, 2001.

CARVAlHO, S.; BROCHIER, M. A.; PIVATO, J.; TEIXEIRA, R. C.; KIELING, R. Ganho de peso, características da carcaça e componentes não-carcaça de cordeiros da raça Texel terminados em diferentes sistemas alimentares. Ciência Rural, Santa Maria, v. 37, n. 3, p. 821-827, 2007.

CASTILHOS, A. M.; BRANCO, R. H.; RAZOOK, A. G.; BONILHA, S. F. M.; MERCADANTE, M. E. Z.; FIGUEIREDO, L. A. Test post-weaning duration for performance, feed intake and feed efficiency in Nellore cattle. Revista Brasileira de Zootecnia, Viçosa, v. 40, n. 2, p. 301-307, 2011.

COCKRUM, R. R.; STOBART, R. H.; LAKE, S. L.; CAMMACK, K. M. Phenotypic variation in residual feed intake and performance traits in rams. Small Ruminant Research, Elsevier, v. 113, n. 2-3, p. 313-3223, 2013.

CRUZ, G. D.; RODRÍGUEZ-SÁNCHEZ， J. A.; OLTJEN, J. W.; SAINZ, R. D. Performance, residual feed intake, digestibility, carcass traits, and profitability of Angus-Hereford steers housed in individual or group pens. Journal of Animal Science, Savoy, v. 88, n. 1, p. 324-329, 2010.

FURUSHO-GARCIA， I. F.; PEREZ， J. R. O.; BONAGURIO, S.; LIMA, A. L.; QUINTÃO, F. A. Estudo dos cortes da carcaça de cordeiros Santa Inês puros e cruzas Santa Inês com Texel, Ile de France e Bergamácia. Revista Brasileira de Zootecnia, Viçosa, v. 33, n. 2, p. 453-462, 2004.
FURUSHO-GARCIA, I. F.; PEREZ, J. R. O.; TEIXEIRA, J. C. Componentes de carcaça e composição de alguns cortes de cordeiros Texel x Bergamácia, Texel x Santa Inês e Santa Inês puros, terminados em confinamento, com casca de café como parte da dieta. Revista Brasileira de Zootecnia, Viçosa, v. 32, n. 6, p. 1999-2006, 2003.

GOMES, R. C.; SAINZ, R. D.; SILVA, S. L.; CÉSAR, M. C.; BONIN, M. N.; LEME, P. Feedlot performance, feed efficiency reranking, carcass traits, body composition, energy requirements, meat quality and calpain system activity in Nellore steers with low and high residual feed intake. Livestock Science, Amsterdam, v. 150, n. 1-3, p. 265-273, 2012.

GROBE, M. D. Características de carcaça e componentes não-carcaça de cordeiros em função do consumo alimentar residual. 2014. Dissertação (Mestrado em Ciência Animal) - Universidade Federal de Lavras, Lavras.

HANKINS, O. G.; HOWE, P. E. Estimation of the composition of beef carcasses and cuts. Washington, D. C.: USDA, 1946. 926 p. (Technical Bulletin).

HERD, R. M.; ARTHUR, P. F. Physiological basis for residual feed intake. Journal of Animal Science, Savoy, v. 87, n. 14, p. 64-71, 2009.

JENSEN, J.; MAO, I. L.; ANDERSEN, B. B.; MADSEN, P. Phenotypic and genetic relationships between residual energy intake and growth, feed intake, and carcass traits of young bulls. Journal of Animal Science, Savoy, v. 70, n. 2, p. 386-395, 1992.

KOCH, R. M.; SWINGER, L. A.; CHAMBERS, D.; GREGORY, K. E. Efficiency of feed use in beef cattle. Journal of Animal Science, Savoy, v. 22, n. 2, p. 486-494, 1963.

LANDIM, A. V.; MARIANTE, A. S.; MCMANUS, C.; GUGEL, R.; PAIVA, S. R. Características quantitativas da carcaça, medidas morfométricas e suas correlações em diferentes genótipos de ovinos. Ciência Animal Brasileira, Goiânia, v. 8, n. 4, p. 665-676, 2007.

MAGNANI, E.; NASCIMENTO, C. F.; BRANCO, R. H.; BONILHA, S. F. M.; RIBEIRO, E. G.; MERCADANTE, M. E. Z. Relações entre consumo alimentar residual, comportamento ingestivo e digestibilidade em novilhas Nelore. Boletim de Indústria Animal, Nova Odessa, v. 70, n. 2, p. 187-194, 2013.

MALHADO, C. H. M.; CARNEIRO, P. L. S.; SANTOS, P. F.; AZEVEDO, D. M. M.; SOUZA, J. C.; AFFONSO, R. M. Curva de crescimento em ovinos mestiços Santa Inês x Texel criados no Sudoeste do Estado da Bahia. Revista Brasileira de Saúde e Produção Animal, Salvador, v. 9, n. 2, p. 210-218, 2008. 
MURO-REYES, A. M.; GUTIERREZ-BANUELOS, H.; DIAZ-GARCIA, L. H.; GUTIERREZ-PINA, F. J.; ESCARENO-SANCHEZ, L. M.; BANUELOSVALENZUELA, R.; MEDINA-FLORES, C. A.; CORRAL-LUNA, A. Potential environmental benefits of residual feed intake as strategy to mitigate methane emissions in sheep. Journal of Animal and Veterinary Advances, Dubai, v. 10, n. 12, p. 1551-1556, 2011.

NASCIMENTO, M. L.; SOUZA, A. R. D. L.; CHAVES, A. S.; CESAR, A. S. M.; TULIO, R. R.; MEDEIROS, S. R.; MOURÃO, G. B.; ROSA, A. N.; FEIJÓ, G. L. D.; ALENCAR, M. M.; LANNA, D. P. D. Fefficiency indexes and their relationships with carcass, non-carcass and meat quality traits in Nellore steers. Meat Science, Barking, v. 116, n. 3, p. 78-85, 2016.

NATIONAL RESEARCH COUNCIL - NRC. Nutrient requirements of small ruminants. $2^{\text {th }}$ ed. Washington, D. C.: National Academy Press, 2007. 362 p.

PASCOAL, L. L.; LOBATO, J. F. P.; RESTLE, J.; VAZ, F. N.; VAZ, R. Z.; MENEZES, L. F. G. Beef cuts yield of steer carcasses graded according to conformation and weight. Revista Brasileira de Zootecnia, Viçosa, v. 39, n. 6, p. 1363-1371, 2010.

PAUlA, E. F. E.; MONTEIRO, A. L. G.; SOUZA, D. F.; PRADO, O. R.; NOMURA, T. M.; STIVARI, T. S. S.; SIlVA, C. J. A.; SANTANA, M. H. A. Consumo alimentar residual e sua relação com medidas de desempenho e eficiência e características in vivo da carcaça de cordeiros. Arquivo Brasileiro de Medicina Veterinária e Zootecnia, Belo Horizonte, v. 65, n. 2, p. 566-572, 2013.

PINHEIRO, R. S. B.; JORGE, A. M. Medidas biométricas obtidas in vivo e na carcaça de ovelhas de descarte em diferentes estágios fisiológicos. Revista Brasileira de Zootecnia, Viçosa, v. 39, n. 2, p. 440-445, 2010.

REDDEN, R. R.; SURBER, L. M. M.; GROVE, A. V.; KOTT, R. W. Effects of residual feed intake classification and method of alfalfa processing on ewe intake and growth. Journal of Animal Science, Savoy, v. 92, n. 2, p. 830-835, 2013a.

REDDEN, R. R.; SURBER, L. M. M.; GROVE, A. V.; KOTT, R. W. Growth efficiency of ewe lambs classified into residual feed intake groups and pen fed a restricted amount of feed. Small Ruminant Research, Elsevier, v. 114, n. 2-3, p. 214-219, 2013 b.

REDDEN, R. R.; SURBER, L. M. M.; ROEDER, B. L.; NICHOLS, B. M.; PATERSON, J. A.; KOTT, R. W. Residual feed efficiency established in a post-weaning growth test may not result in more efficient ewes on the range. Small Ruminant Research, Elsevier, v. 96, n. 1-2, p. 155-159, 2011.

REIS, S. F.; FAUSTO, D. A.; MEDEIROS, S. R.; PAULINO, P. V. R.; VALADARES FILHO, S. C.; TORRES JÚNIOR, R. A. A. Feed efficiency and meat quality of crossbred beef heifers classified according to residual feed intake. Revista Brasileira de Saúde e Produção Animal, Salvador, v. 16, n. 3, p. 632-642, 2015.

REYNOLDS, C. K. Economics of visceral energy metabolism in ruminants: toll keeping or internal revenue service? Journal of Animal Science, Savoy, v. 80, n. 2, p. 74-84, 2002.

RIBEIRO, E. L. A; OLIVEIRA, H. C.; CASTRO, F. A. B; MiZUBUTI, I. Y.; SILVA, L. D. F. da; BARBOSA, M. A. A. F. Desempenho em confinamento e componentes do peso vivo de cordeiros mestiços de três grupos genéticos. Ciência Rural, Santa Maria, v. 39, n. 7, p. 2162-2168, 2009.

RICARDO, H. A.; ROÇA, R. O.; LAMBE, N. R.; SENO, L. O.; FUZIKAWA, H. I. S.; FERNANDES, A. R. M. Prediction of weight and percentage of salable meat from Brazilian market lambs by subjective conformation and fatness scores. Revista Brasileira de Zootecnia, Viçosa, v. 45, n. 10, p. 693-644, 2016.

RICHARDSON, E. C.; HERD, R. M.; ODDY, V. H.; THOMPSON, J. M.; ARCHER, J. A.; ARTHUR, P. F. Body composition and implications for heat production of Angus steer progeny of parents selected for and against residual feed intake. Australian Journal of Experimental Agriculture, Melbourne, v. 41, n. 7, p. 1065-1072, 2001.

RICHARDSON, E. C.; HERD, R. M. Biological basis for variation in residual feed intake in beef cattle. 2 . Synthesis of results following divergent selection. Australian Journal of Experimental Agriculture, Melbourne, v. 44, n. 3, p. 431-440, 2004.

SANCHES, A. C.; REYES, A.; PAUlinO, V. R.; BULLE, F. C. P. C.; SAINZ, R. D. Leptina plasmática e característica de carcaça em novilhos de corte de alto e baixo consumo alimentar residual. In: REUNIÃO ANUAL DA SOCIEDADE BRASILEIRA DE ZOOTECNIA. 43., 2006. João Pessoa. Anais... João Pessoa: [s.n.], 2006. CD-ROM.

SEAL, C. J.; REYNOLDS, C. K. Nutritional implications of gastrointestinal and liver metabolism in ruminants. Nutrition Research Reviews, Cambridge, v. 6, n. 1, p. 185-208, 1993.

SHARIFABADI, H. R.; NASERIAN, A. A.; VALIZADEH, R.; NASSIRY, M. R.; BOTTJE, W. G.; REDDEN, R. R. Growth performance, feed digestibility, body composition, and feeding behavior of high - and 
low residual feed intake fat-tailed lambs under moderate feed restriction. Journal of Animal Science, Champaign, v. 94, n. 8, p. 3382-3388, 2016.

SHARMA, V. K.; KUNDU, S. S.; PRUSTY, S.; DATT, C.; KUMAR, M. Nutrient utilisation, growth performance and blood metabolites in Murrah buffalo calves (Bubalus bubalis) divergently selected for residual feed intake. Archives of Animal Nutrition, London, v. 70, n. 6, p. 455-469, 2016.

SNIFFEN, C. J.; CONNOR, J. D.; VAN SOEST, P.; FOX, D. G.; RUSSEL, J. B. A net carbohydrate and protein system for evalution cattle diets. II. Carboydrate and protein availability. Journal of Animal Science, Savoy, v. 70, n. 11, p. 3562-3577, 1992.

SOBRINHO, T. L.; BRANCO, R. H.; BONILHA, S. F. M.; CASTILHOS, A. M.; FIGUEIREDO, L. A.; RAZZOK, A. G.; MERCADANTE, M. E. Z. Residual feed intake and relationships with performance of Nellore cattle selected for post weaning weight. Revista Brasileira de Zootecnia, Viçosa, v. 40, n. 4, p. 929-937, 2011.
STATISTICAL ANALYSIS SYSTEM INSTITUTE SAS Institute statistical analysis system. SAS versão 9.2. Cary: SAS Inst. Inc., 2009.

VAN SOEST, P. J.; ROBERTSON, J. B.; LEWIS, B. A. Symposium: carbohydrate methodology, metabolism, and nutritional implications in dairy cattle. Journal of Dairy Science, Cambridge, v. 74, n. 2, p. 3583-3597, 1991.

VILLARROEL, A. B. S.; LIMA, L. E. S.; OLIVEIRA, S. M. P.; FERNANDES, A. A. O. Ganho de peso e rendimento de carcaça de cordeiros mestiços Texel e Santa Inês x SRD em sistema de manejo semi-intensivo. Ciência e Agrotecnologia, Lavras, v. 30, n. 5, p. 971-976, 2006.

WANG, Z.; NKRUMAH, J. D.; LI BASARAB, J. A.; GOONEWARDENE, L. A.; OKINE, E. K.; CREWS, J. D.; MOORE, S. S. Test duration for growth, feed intake, and feed efficiency in beef cattle using the growsafe system. Journal of Animal Science, Savoy, v. 84, n. 9, p. 2289-2298, 2006. 